\title{
NECROTIZING PANCREATITIS: THE WAYS OF IMPROVEMENT OF SURGICAL TREATMENT
}

\author{
O.V. Rozenko \\ DONETSK NATIONAL MEDICAL UNIVERSITY, MARIUPOL, UKRAINE
}

Background. In connection with a steady increase of patients with destructive forms of acute pancreatitis, the proportion of which takes from 10-15 to 20-30\%, despite of the wide range of treatments for non-biliary necrotizing pancreatitis, the rate of mortality reaches $80-90 \%$ in case of infected forms and needs further improvement of therapies.

Objective. The purpose of this study is to improve the results of treatment of patients with nonbiliary necrotizing pancreatitis, by optimizing surgical tactics.

Methods. The study examined the cases of 120 patients, whose age ranged from 22 to 83 years, including patients under the age of 50 years old who accounted for $60.0 \%$. There were 80 males (66.7\%) and 40 females (33.3\%). Disease duration up to 24 hours was found in 36 (30.0\%) patients, from 25 to 72 hours - in 25 (20.8\%) individuals, more than 72 hours - in 49 (49.2\%) patients.

Results. The research claims in non-necrotizing pancreatitis, left-sided retroperitoneal phlegmon often develops in $64.2 \%$ (mortality rate 26.0\%) of patients, right-sided in $24.2 \%$ (mortality rate 6.8\%) of patients, and bilateral - in 11, 6\% (mortality rate 64.2\%) individuals. Moreover, the highest mortality was observed with a combination of retroperitoneal phlegmon cellulose and abscess of the pancreas and/or omental bursa-39.1\%.

Conclusions. The use of various surgical interventions depending on the involvement in the pathological process of various sections of the abdominal cavity/ retroperitoneal space, which made it possible to reduce mortality and hospitalization time of patients in the hospital by 1.5-2 times is proposed.

KEY WORDS: necrotizing pancreatitis; lumbotomy; parapancreatic fiber; phlegmon of the retroperitoneal tissue; laparotomy; omentobursostomy.

\section{Introduction}

During the last decade, a steady increase in patients with destructive forms of acute pancreatitis has been observed, the proportion of which takes from $10-15$ to $20-30 \%$ at the pathology of the abdominal organs. According to many authors, the main causes of high mortality rate are the duration of the disease, the prevalence of pancreatic necrosis and parapancreatic fiber, inadequate selection of the method of surgical and anesthesia, and drug therapy $[1,2,3]$. The variety of surgical treatment (from traditional laparotomy, lumbotomy to puncture-draining operations under the ultrasound control, using various methods of drainage of the abdominal cavity and retroperitoneal tissue) is determined by the clinical form of infected pancreatitis (abscess of the pancreas and/or the lesser sac, the abscess of the abdominal pancreatitis and/ or the lesser sac, the abscess of the abdominal

*Corresponding author: Oleg V. Rozenko, MD, Ph.D., Associate Professor, Department of Surgery, Endoscopy, Otorhinolaryngology and Reconstructive Surgery, Donetsk National Medical University, e-mail: oleg.rozenko@gmail.com. pancreatitis and/or the omental purulent peritonitis). Extraperitoneal access to infected foci of pancreatic necrosis is one of the options for surgical treatment of necrotizing pancreatitis, the advantages of which are less trauma, the absence of infection of the abdominal cavity, a reduction in the number of complications (intestinal fistula, bleeding), the possibility of epidural anesthesia, faster recovery of intestinal function and early enteral nutrition $[4,5,6]$.

The peak of surgical activity occurs during 2-3 weeks of illness when necrosis of the pancreas and parapancreatic fiber has already developed certain limits (the prevalence of pancreatic necrosis), the process of biological sequestration is completed and the possibility of removal of sequestered and necrotized tissues has appeared. During the primary operation, it is not always possible to visualize the boundaries of healthy and necrotic modified pancreatic tissue and parapancreatic fiber which limits necral and sequestrectomy due to possible damage to the parenchyma of the 
gland and the threat of bleeding that makes it impossible for one-time sanitation and adequate drainage of all purulent-necrotic cavities. Therefore, a number of authors propose to leave non-invested tissues, to drain the affected section of the retroperitoneal tissue, suggesting further programmatic step-by-step revisions and sequestrectomy. The clinical meaning of the division of sanations into stages is also due to the non-simultaneous maturation of sequesters, the secondary progression of the purulent process according to the type of leakages, the danger of septic shock with the simultaneous opening of extensive retroperitoneal ulcers $[7,8,9]$.

Despite the wide range of treatments for infected necrotizing pancreatitis, the rate of mortality remains quite high. When analyzing the causes of deaths, inadequate drainage of the pancreatic area with necrosis of parapancreatic fiber, the formation of phlegmon or multiple abscesses in the retroperitoneal space is almost always established [10,11, 12].

The objectives of this study are to improve the results of treatment of patients with nonbiliary necrotizing pancreatitis, by optimizing surgical tactics (use of lumbotomy), depending on the prevalence of necrosis in the pancreas and retroperitoneal tissue.

\section{Methods}

The study examined the cases of 120 patients who were hospitalized at the Mariupol City Pancreatic Center at the Department of Surgery, Endoscopy and Reconstructive Surgery at Donetsk National Medical University from 2014-2018. The age of patients ranged from 22 to 83 years, including patients under the age of 50 years old who accounted for $60.0 \%$. There were 80 males (66.7\%) and 40 females (33.3\%). Disease duration up to 24 hours was found in $36(30.0 \%)$ patients, from 25 to 72 hours - in 25 $(20.8 \%)$ individuals, more than 72 hours - in 49 (49.2\%) patients.

The study was conducted in accordance with the principles of bioethics, patients had given informed consent.

The causes of acute non-biliary necrotizing pancreatitis were the following ones: unilateral feeding (excessive intake of predominantly fatty foods) - in $62(51.7 \%)$ patients and intake of alcohol (alcoholic excess) or its surrogates - in $58(48.3 \%)$ individuals.

Limited pancreatic necrosis (less than $30 \%$ necrosis of pancreatic parenchyma) was found in $10(8.3 \%)$ patients, the spread one (from 30 to $50 \%$ necrosis of pancreatic parenchyma) - in $68(56.7 \%)$ individuals, and subtotal-total (more than $50 \%$ of necrosis of the pancreatic parenchyma) - in 42 (35.0\%) patients.

Retroperitoneal cellulose phlegmon with diffuse purulent peritonitis due to involvement in the inflammatory process of the peritoneum was detected in $9(7.5 \%)$ patients, retroperitoneal cellulitis without peritonitis - in $90(75.0 \%)$ individuals, and a combination of retroperitoneal phlegmon and pancreatic abscess and/or omental patient bag - in 21 (17.5\%) cases.

Left-side retroperitoneal phlegmon was detected in $77(64.2 \%)$ patients, right-side retroperitoneal phlegmon in 29 (24.2\%), and bilateral retroperitoneal phlegmon - in $14(11.6 \%)$. Verification of phlegmon of the retroperitoneal tissue was carried out on the basis of data obtained during the ultrasound examination, computer tomography, and surgery (macroscopic evaluation of retroperitoneal tissue sequestration, detritus), as well as bacteriologically.

All patients received intensive therapy, including hunger, gastric drainage, catheterization of the central vein and bladder, infusiontransfusion therapy in a volume of not less than $40 \mathrm{ml} / \mathrm{kg}$ body weight with a ratio of colloidal and crystalloid solutions of 1:4; analgesia: epidural blockade at the level of Th7-9 (method of choice: continuous infusion of $0.2 \%$ lidocaine solution with a speed of $6-12 \mathrm{ml} /$ hour), nonsteroidal anti-inflammatory drugs (ketoprofen $100 \mathrm{mg} 3$ times a day); antisecretory therapy (the optimal period is the first three days of the disease): the drugs of choice are sandostatin (octreotide) $100 \mathrm{mg} 3$ times a day subcutaneously and omeprazole $40 \mathrm{mg} 2$ times a day IV; reserve drugs 5 - fluorouracil $(5 \%-5 \mathrm{ml}$ i.v.) and quamel $40 \mathrm{mg} 2$ times a day i.v. antienzyme therapy (optimal duration - the first 5 days of the disease): contraction of at least 50,000 units/day, pride at least 500,000 units/day; prevention of purulent complications: pefloxacin, $400 \mathrm{mg}$ 2 times a day, i.v. + metronidazole, $500 \mathrm{mg}$, 3 times a day, i.v., with signs of secondary infection: cefoperazone / sulbactam, cefepime, imipenem, meropenem. With the ineffectiveness of the above activities, resorted to extracorporeal detoxification methods (Iympho-sorption, plasmapheresis, etc.). However, the effect was temporary and unstable, which required the need for rehabilitation of extensive purulentnecrotic foci with laparotomy followed by closed drainage of the abdominal cavity and retroperitoneal space. 


\section{Results}

A total of $31(25.8 \%)$ patients died after surgery. The causes of death in 29 patients were sepsis and multiple organ failure, in 1 case sepsis and multiple intestinal fistulas, in 1 case erosive bleeding from the splenic artery.

The severity of necrotizing pancreatitis during the first 24 hours was assessed according to the criteria of systemic inflammatory response syndrome ( 2 or more signs) and additional risk factors: patient age, body mass index (over 30), hematocrit, APACHE II score (more than 8 points), C-reactive protein indicator (more than $120 \mathrm{mg} / \mathrm{L}$ ). And after 24 hours - on the scales of assessment of Marshall's multi-organ dysfunction (MODS) or SOFA.

Lumbotomy was performed under general anesthesia or epidural anesthesia. The lumbotomy of the left mini-access was performed as follows: below the arc of the XII rib, the skin and subcutaneous tissue is dissected $2-3 \mathrm{~cm}$ from the middle axillary to the back axillary line, pushing the muscle mass apart, the parietal peritoneum is exposed. Paracolous fiber is reached with the fingers, exfoliating the peritoneum medially, focusing on the lower pole of the spleen and the left kidney. The abscess was opened by means of an electric suction, the pus was removed, the retroperitoneal fiber affected by enzymatic aggression (free-lying sequesters). Necrectomy is not performed due to the risk of damage to the "healthy" parenchyma of the pancreas, parapancreatic fiber and large vessels. The purulent necrotic cavity was sanitized and drained by elastic silicone drains. The lumbotomy of the right mini-approach is similar to the method described above, but the guidelines for advancing in the retroperitoneal space are the lower edge of the right lobe of the liver (its posterior surface), the right kidney, the head of the pancreas, the hepatoduodenal ligament.

When the purulent-necrotic lesion spreads to the paracolous tissue, the dissection and drainage of the abscesses was performed through the front mini-accesses in the left or right iliac regions, respectively, using the Volkovich incision up to $4-5 \mathrm{~cm}$ long. The iliac regions were moved apart. The parietal peritoneum with the mesentery of the sigmoid (cecum) intestine inwardly exfoliated by stupid fingers and wet tupffers. Next, the surgeon with his fingers penetrates into the paracollate tissue of the retroperitoneal regions. Tissue separation should occur easily and almost bloodless. Flow-through drainage of phlegmon on the left was performed by two approaches: lumbotomy with a mini-access to the left and anterior mini-access in the iliac region. Separation of retroperitoneal tissue from the anterior approach on the right should be made to the level of the pancreatic head.

The purpose of surgical intervention (lumbotomy) in case of infected parapancreatitis is adequate opening and drainage (by elastic silicone drains) of the abscess with destruction of cell bridges, leakages, removal of purulent exudate, loosely sequestered, creating a single well-drained cavity for the next year. In an emergency procedure, about retroperitoneal phlegmon and diffuse purulent peritonitis, caused by the involvement of the parietal peritoneum in the inflammatory process, 9 (7.5\%) patients were operated on. All of them performed laparotomy, dissection of phlegmon, sanitation and drainage of the stuffing box and abdominal cavity. In 6 patients, the operation was completed by imposing a laparostomy and in the postoperative period, programmed rehabilitation of the abdominal cavity was performed, and in 1 patient the left lumbotomy was also performed. 3 patients died with left-sided localization of the abscess; postoperative mortality was $22.2 \%$. The cause of death was sepsis and multiple organ failure.

\section{Discussions}

Retroperitoneal cellulose phlegmon without peritonitis was an indication for performing surgical interventions in $88(73.3 \%)$ patients. 20 patients died; the mortality rate was $22.7 \%$. The cause of death was sepsis and multiple organ failure.

In $40(45.4 \%)$ patients, laparotomy, dissection and drainage of retroperitoneal phlegmon, sanitation and drainage of the abdominal cavity were used as a surgical aid. In 3 (7.9\%) patients, surgery was supplemented with lumbotomy. 14 patients died, including 8 patients with leftsided retroperitoneal cellulitis, 2 individuals with right-sided and 4 patients with bilateral ones. Mortality rate was $32.5 \%$. The cause of death was sepsis and multiple organ failure.

In $24(27.3 \%)$ patients, puncture-draining surgical interventions under the control of ultrasound (POD-UZ) were applied. In addition, 9 patients underwent lumbotomy and 1 - laparotomy, sequestrectomy, omentobursostomy due to the localization of sequesters in the pancreatic head region. 4 (16.6\%) patients died, sepsis and PON were the causes of death, and in 1 patient was with bleeding from acute gastric and duodenal ulcers. 
In $24(27.3 \%)$ patients with phlegmon of the retroperitoneal tissue in the form of "purulent cells", lumbotomy, sequestrectomy, and drainage of the retroperitoneal tissue were performed. 3 patients underwent laparotomy, sequestrectomy, omentobursostomy in connection with the localization of sequestrum in the pancreatic head region; 2 patients died. The rate of mortality was $8.3 \%$. In 1 case, there was a left-sided lesion of retroperitoneal fat, in 1 patient - bilateral one.

Approximately $23(19.2 \%)$ patients were operated on the combination of retroperitoneal phlegmon with abscess of the pancreas and/ or omental bursa. After surgery, 9 patients died, the mortality rate was $39.1 \%$. In $8(30.4 \%)$ patients, laparotomy, necropsy and drainage of abscesses, sanitation and drainage of the abdominal cavity were used as surgical aids. 5 patients died, mortality was $62.5 \%$. All the dead individuals had a left-sided lesion of retroperitoneal fat. The cause of death in 4 patients was sepsis and multiple organ failure, in 1 sepsis and multiple intestinal fistulas.

A combination of various surgical procedures was used in 15 (65.2\%) patients with retroperitoneal phlegmon cellulose. In 13 patients, a pancreas abscess and/or omental bursa was performed with PDO-UZ, and about retroperitoneal phlegmon - lumbotomy, sequestrectomy, drainage of retroperitoneal fat. Including 2 patients, a laparotomy and an omentobursostomy were performed by the third stage in order to remove large sequesters located in the region of the head and body of the pancreas.

In 2 patients at the first stage, PDO-UZ about the retroperitoneal phlegmon in the form of fluid accumulation were performed, followed by laparotomy, omentobursostomy, opening of the stuffing box abscess, sequestrectomy. In total, 4 patients died in this subgroup, the mortality rate was $26.7 \%$. In 2 patients, leftsided localization of retroperitoneal phlegmon cellulose was detected, in 2 patients, bilateral. The causes of death were sepsis and multiple organ failure - in 3 patients, bleeding from the arrosive splenic artery - in 1 patient.

The analysis of the data suggests that leftsided retroperitoneal phlegmon often develops in $64.4 \%$ of patients with infected non-biliary necrotizing pancreatitis. Right-sided retroperitoneal phlegmon was found in $25 \%$ of patients, and bilateral - in $10.6 \%$. At the same time, the highest mortality rate is observed with bilateral phlegmon of retroperitoneal tissue $-63.6 \%$, with the left-sided it was $-26.9 \%$, and with the right-sided $-7.7 \%$. Moreover, the highest mortality is observed with a combination of retroperitoneal phlegmon cellulose and abscess of the pancreas and/or omental bursa $-41.2 \%$. With phlegmon of the retroperitoneal fiber and diffuse purulent peritonitis caused by the involvement of the parietal peritoneum in the inflammatory process, it was $28.6 \%$, and with the abscess of the retroperitoneal fat without peritonitis - $22.5 \%$.

The analysis of the results of the use of various surgical interventions in the case of phlegmon of the retroperitoneal tissue suggests that the use of laparotomy in the case of the phlegmon of the retroperitoneal tissue is accompanied by the highest mortality rate $34.9 \%$. In this regard, this operation should not be used to treat retroperitoneal phlegmon with the exception of patients with retroperitoneal cellulitis and diffuse purulent peritonitis, due to the involvement of the parietal peritoneum in the inflammatory process. Somewhat better results were obtained from the use of puncture draining operations under the control of ultrasound $-16.7 \%$. However, according to our data, they were effective in $28.6 \%$ of patients with retroperitoneal phlegmon cellulose in the form of free fluid accumulation. Mortality after lumbotomy was $13.3 \%$. This operation was performed in $71.4 \%$ of patients with retroperitoneal phlegmon cellulose in the form of "purulent cells", incl. in $21.4 \%$ of patients in whom the use of PDO-Ultrasound was ineffective. Thus, the opening of the retroperitoneal tissue from the mini-accesses (lumbotomy, sequestrectomy, drainage of the retroperitoneal tissue) is the most popular surgery for retroperitoneal phlegmon. However, as our experience has shown one opening of retroperitoneal phlegmon cellulose is not enough. In the absolute majority of patients, there was a need to perform stepby-step rehabilitation of retroperitoneal fat (step-down sequestrectomy).

Comparing the results of our patients' treatment with similar indicators of other medical institutions, similar methods of surgical interventions were used, we established certain features (Table 1).

In the most severe category of patients, where diffuse purulent peritonitis and retroperitoneal phlegmon were combined, the rates of postoperative mortality did not differ significantly among themselves, they also did not have significant differences in patients with isolated phlegmon of retroperitoneal tissue without peritonitis. 
Table 1. Comparative results of treatment of patients with the traditional method and with the use of puncture-draining operations

\begin{tabular}{|c|c|c|c|c|c|c|}
\hline \multirow{4}{*}{$\begin{array}{c}\text { Patient } \\
\text { categories }\end{array}$} & \multicolumn{6}{|c|}{ Indicators of treatment } \\
\hline & \multicolumn{2}{|c|}{$\begin{array}{c}\text { Repeated surgical } \\
\text { interventions } \\
\text { (progressive diseases) }\end{array}$} & \multicolumn{2}{|c|}{$\begin{array}{c}\text { Postoperative } \\
\text { mortality }\end{array}$} & \multicolumn{2}{|c|}{$\begin{array}{l}\text { Average length } \\
\text { of hospital stay }\end{array}$} \\
\hline & \multicolumn{6}{|c|}{ Types of surgical interventions } \\
\hline & $\begin{array}{l}\text { Puncture- } \\
\text { draining } \\
\text { operations } \\
\text { and/or } \\
\text { lumbotomy } \\
\text { with } \\
\text { mini-access }\end{array}$ & $\begin{array}{l}\text { Traditional } \\
\text { interven- } \\
\text { tions } \\
\text { laparotomy } \\
\text { and/or } \\
\text { lumbotomy }\end{array}$ & $\begin{array}{c}\text { Puncture- } \\
\text { draining } \\
\text { operations } \\
\text { and/or } \\
\text { lumbotomy } \\
\text { with } \\
\text { mini-access }\end{array}$ & $\begin{array}{l}\text { Traditional } \\
\text { interven- } \\
\text { tions } \\
\text { laparotomy } \\
\text { and/or } \\
\text { lumbotomy }\end{array}$ & \begin{tabular}{|} 
Puncture- \\
draining \\
operations \\
and/or \\
lumbotomy \\
with \\
mini-access
\end{tabular} & $\begin{array}{l}\text { Traditional } \\
\text { interven- } \\
\text { tions } \\
\text { laparotomy } \\
\text { and/or } \\
\text { lumbotomy }\end{array}$ \\
\hline $\begin{array}{l}\text { Isolated abscess } \\
\text { and/or phleg- } \\
\text { mon-retroperito- } \\
\text { neal tissue } \\
\text { (purulent- } \\
\text { necrotic phase) }\end{array}$ & $3,3 \%$ & $6,5 \%$ & $39,1 \%$ & $48,2-62,5 \%$ & $32,5 \pm 2,5$ & $48 \pm 3,6$ \\
\hline $\begin{array}{l}\text { Phlegmon-retro- } \\
\text { peritoneal tissue } \\
\text { in the form of an } \\
\text { accumulation of } \\
\text { free fluid and/or } \\
\text { an abscess of the } \\
\text { pancreas of the } \\
\text { omental bursa }\end{array}$ & $2,8 \%$ & $5,4 \%$ & $26,7 \%$ & $36,5-42,2 \%$ & $28,7 \pm 2,5$ & $46 \pm 2,8$ \\
\hline
\end{tabular}

But when using puncture-draining operations of the pancreas abscesses and opening the phlegmon of retroperitoneal tissue from a mini-access of our patients, it made it possible to reduce slightly the mortality rates in comparison with other clinical hospitals. This figure of our patients was $39.1 \%$ as in other clinics reached $62.5-48.2 \%[1,3]$. Also, significant differences in the results of treatment of our patients were obtained with the early use of puncture-draining operations for fluid accumulation in the retroperitoneal tissue and isolated abscess of the pancreas and/or omental bursa $27.6 \%$ in our clinic and 36,6-42.2 in other medical institutions $[11,6]$.

At the same time, it is recommended to use PDO-Ultrasound for abscesses of the pancreas and/or omental bursa, and laparotomy, sequestrectomy and otobursostomy to remove sufficiently large sequesters located in the head and body of the pancreas.

\section{Conclusions}

In cases of retroperitoneal fat phlegmon and diffuse purulent peritonitis caused by involvement of parietal peritoneum in the inflam- matory process, the preferred treatment is laparotomy, sanitation, and drainage of abdominal, extraperitoneal phlegmon dissection, and retroperitoneal fiber drainage draining followed by with the subsequent programmed sanitation of the abdominal cavity and retroperitoneal tissue.

In cases of postnecrotic infected pancreatic and/or parapancreatic fluid accumulations in the retroperitoneal tissue (abscess of the retroperitoneal tissue) in the form of purulent soaking of cellulose spaces of the "honeycomb" type, the operation of choice is the direct surgical intervention on the pancreas and retroperitoneal tissue from the mini-access (extraperitoneal access - lumbotomy), followed by staged sequestrectomy.

Puncture-draining surgical interventions under the ultrasound control can only be used with retroperitoneal phlegmon cellulose in the form of free fluid accumulation.

In the presence of sequesters of large size, which are located in the head and body of the pancreas, the operation of choice is a laparotomy, sequestrectomy, omentobursostomy. 


\section{Acknowledgements}

The author is gratefully acknowledged to Olena Sydorenko (PhD in Philology, Associate Professor) with the help in translation of this article.

\section{Funding}

This research received no external funding. Conflict of Interests

The author declares no conflict of interests.

\section{НЕКРОТИЧНИЙ ПАНКРЕАТИТ: ШЛЯХИ УДОСКОНАЛЕННЯ ХІРУГІЧНОГО ЛІКУВАННЯ}

О.В. Розенко

ДОНЕЦЬКИЙ НАЦІОНАЛЬНИЙ МЕДИЧНИЙ УНІВЕРСИТЕТ, УКРАЇНА

Вступ. Узв'язку з неухильним зростанням кількості пацієнтів із деструктивними формами гострого панкреатиту, питома вага якого складає від 10-15 до 20-30\%, незважаючи на широкий спектр способів лікування небіліарного некротичного панкреатиту, летальність досягає у випадку інфікованих форм 80-90\% і потребує подальшого дослідження та поліпшення методів лікування.

Мета. Метою дослідження є поліпшення результатів лікування хворих на небіліарний некротичний панкреатит шляхом оптимізації хірургічної тактики.

Методи. До дослідження залучено 120 пачієнтів віком від 22 до 83 років, причому пацієнти віком до 50 років склали 60,0\%. Чоловіків було 80 (66,7\%), жінок - 40 (33,3\%). Тривалість захворювання до 24 годин визначено у 36 (30,0\%) хворих, від 25 до 72 годин - у 25 (20,8\%), більше ніж 72 години - у 49 (49,2\%).

Результати. Установлено, що у випадку небіліарного некротичного панкреатиту частіше розвивається лівобічна заочеревинна флегмона - у 64,2\% (летальність 26,0\%) пацієнтів, правобічна виявлена у 24,2\% (летальність 6,8\%) пацієнтів, а двобічна -у 11, 6\% (летальність 64,2\%). Також найбільш високу летальність засвідчено в поєднанні флегмони заочеревинної клітковини й абсцесу підшлункової залози і/або сальникової сумки - 39,1\%.

Висновки. Автори дослідження запропонували різні варіанти хірургічного втручання залежно від залучення до патологічного процесу різних відділів черевної порожнини/заочеревинного простору, що дозволило знизити летальність і час перебування пацієнтів у стаціонарі в 1,5-2 рази.

КЛЮЧОВІ СЛОВА: небіліарний панкреатит; люмботомія; парапанкреальна клітковина; флегмона заочеревинної клітковини; лапаратомія; оментобурсостомія.

Інформація про автора

Розенко Олег Володимирович - канд. мед. наук, доцент кафедри хірургії, ендоскопії, оториноларингології та реконструктивно-відновлювальної хірургії, Донецький національний медичний університет.

Information about the author

Oleg V. Rozenko - MD, Ph.D., Associate Professor, Department of Surgery, Endoscopy, Otorhinolaryngology and Reconstructive Surgery, Donetsk National Medical University

ORCID https://orcid.org/0000-0003-3434-6221, e-mail: oleg.rozenko@gmail.com

\section{References}

1. Baron TH, DiMaio CJ, Wang AY, Morgan KA. American Gastroenterological Association clinical practice update: management of pancreatic necrosis. Gastroenterology. 2020 Jan 1;158(1):67-75.
2. Lu JD, Cao F, Ding YX, Wu YD, Guo YL, Li F. Timing, distribution, and microbiology of infectious complications after necrotizing pancreatitis. World Journal of Gastroenterology. 2019 Sep 14;25(34):5162. 
3. Ocampo C, Zandalazini H, Alonso F, Canullan C, Stagnaro G, Leyton V, Chiappetta L. A Multimodal Approach for the First-Line Treatment of Infected Pancreatic Necrosis. Pancreas. 2020 Jul 1;49(6):757-62.

4. Bugiantella W, Rondelli F, Boni M, Stella P, Polistena A, Sanguinetti A, Avenia N. Necrotizing pancreatitis: $A$ review of the interventions. International journal of surgery. 2016 Apr 1;28:S163-71.

5. Halkic N, Pezzetta E, Abdelmoumene A. Indications and results of retroperitoneal laparostomy in the treatment of infected acute necrotizing pancreatitis. 2003; 58 (1): 97-99.

6. Amano HJ. Therapeutic intervention and surgery of acute pancreatitis. J. Hepatobiliary pancreat 2010; 17 (1): 57-59.

7. Bartholdy A, Werge M, Novovic S, Hadi A, Nøjgaard C, Borch A, Feldager E, Gluud LL, Schmidt PN. Endoscopic treatment with transmural drainage and necrosectomy for walled-off necrosis provides favourable long-term outcomes on pancreatic function. United European Gastroenterology Journal. 2020 Jun;8(5):552-8.

8. Lan L, Luo J, Yang $X$, Yang D, Li M, Chen F, Zeng N, Zhou X. Association between Timing of
Surgical Intervention and Mortality in 15,813 Acute Pancreatitis. Computational and Mathematical Methods in Medicine. 2020 May 16;2020.

9. Connor S. Surgery in the treatment of acute pancreatitis - minimal access pancreatic necrosectomy. Scand J. Surg. 2005; 94 (2): 135-42.

10. Tu Y, Jiao H, Tan X, Sun L, Zhang W. Laparotomy versus retroperitoneal laparoscopy in debridement and drainage of retroperitoneal infected necrosis in severe acute pancreatitis. Surgical endoscopy. 2013 Nov 1;27(11):4217-23.

11. Sharma P, Sharma S, Yadav A, Rotem E. CT guided percutaneous drainage in necrotizing pancreatitis-highly successful in appropriately selected patients-single center experience. Journal of the Pancreas. 2019 Jan 1;20(1):24-9.

12. Luckhurst $C M$, El Hechi M, Elsharkawy $A E$, Eid AI, Maurer LR, Kaafarani HM, Thabet A, Forcione DG, Fernández-Del Castillo C, Lillemoe KD, Fagenholz PJ. Improved mortality in necrotizing pancreatitis with a multidisciplinary minimally invasive step up approach: comparison to a modern open necrosectomy cohort. Journal of the American College of Surgeons. 2020 Apr 3.

Received 30 March 2020; revised 18 May 2020; accepted 09 June 2020.

This is open access article distributed under the Creative Commons Attribution License, which permits unrestricted use, distribution, and reproduction in any medium, provided the original work is properly cited. 